\title{
Article \\ Biochemical Changes in Vitis vinifera Buds between Dormancy and Forced Bursting: A Case Study of Three Portuguese White Varieties
}

\author{
Ana I. Monteiro*(D), Alfredo Aires (D), Aureliano C. Malheiro*(D) and Eunice A. Bacelar (D)
}

Citation: Monteiro, A.I.; Aires, A.; Malheiro, A.C.; Bacelar, E.A. Biochemical Changes in Vitis vinifera Buds between Dormancy and Forced Bursting: A Case Study of Three Portuguese White Varieties. Agronomy 2022, 12, 382. https:// doi.org/10.3390/agronomy12020382 Academic Editor: Gianluca Allegro

Received: 29 December 2021

Accepted: 1 February 2022

Published: 3 February 2022

Publisher's Note: MDPI stays neutral with regard to jurisdictional claims in published maps and institutional affiliations.

Copyright: (C) 2022 by the authors. Licensee MDPI, Basel, Switzerland. This article is an open access article distributed under the terms and conditions of the Creative Commons Attribution (CC BY) license (https:// creativecommons.org/licenses/by/ $4.0 /)$
Centre for the Research and Technology of Agro-Environmental and Biological Sciences (CITAB), University of Trás-os-Montes e Alto Douro, 5000-801 Vila Real, Portugal; alfredoa@utad.pt (A.A.); areale@utad.pt (E.A.B.)

* Correspondence: anamonteiro@utad.pt (A.I.M.); amalheir@utad.pt (A.C.M.)

\begin{abstract}
The transition between the dormancy and budburst is accompanied by physiological and biochemical changes, which include variations in the carbohydrates, enzymatic activity, as well as hormones present inside the buds. The present study aimed to evaluate the biochemical changes that occur in dormant buds and forced bursting of three Vitis vinifera L. white varieties (Alvarinho, Fernão-Pires, and Loureiro) from two vineyards located in the Vinhos Verdes Demarcated Region, NW Portugal. For this purpose, the contents of malondialdehyde (MDA), proline, carbohydrates, and gibberellic acid $\left(\mathrm{GA}_{3}\right)$, as well as antioxidant enzymes activity were analysed. The results showed that the MDA, proline, total soluble sugars, and $\mathrm{GA}_{3}$ contents tended to be higher at budburst. In contrast, the starch content was higher at dormancy. The enzymatic activities of ascorbate peroxidase (APX), peroxidase (POX), and superoxide dismutase (SOD) were lower at budburst, compared with dormancy, while the reverse was observed in catalase (CAT). Significant differences were also observed between varieties for most biochemical parameters analysed, with the exception of CAT activity. Alvarinho stood out from other varieties for presenting higher MDA, proline, soluble sugars, and $\mathrm{GA}_{3}$ content, while Fernão-Pires displayed higher values of APX and POX activities and starch content. To our knowledge, the present work is the first attempt to examine the biochemical changes in dormant buds and bursting, which determine the vegetative and reproductive continuity of grapevines. This information contributes to better vineyard management, particularly important in light of the climate change scenarios, which can affect the biochemical mechanisms of the buds and compromise the yield and quality of grapevines.
\end{abstract}

Keywords: carbohydrates; enzymatic activity; grapevine; lipid peroxidation; gibberellic acid

\section{Introduction}

In temperate climates, such as NW Portugal, the decrease in temperature and photoperiod induces grapevines to enter a period of dormancy, to survive due to unfavourable environmental conditions [1,2]. To ensure their survival during this cold period, grapevines set some special mechanisms, such as suspension of visible growth, reduced metabolic and enzymatic activity, accumulating carbohydrates (soluble sugars and starch), changes in endogenous plants growth regulators, and decreased in tissue water content [1,3-6]. However, at this stage, buds do not remain completely inactive, and the essential metabolic and respiratory activities continue to occur but at a lower intensity [4-6]. After a period of chilling accumulation, dormancy is broken, and buds start to burst. Budburst marks the visible, physiological 'awakening' (active period) of grapevines after a period of dormancy. This process is environmentally mediated by variety-specific responses to temperature and the photoperiod and by intrinsic factors [7-9]. This stage involves metabolic and physiological changes-namely, in respiration rate, growth regulators, carbohydrate metabolism, and tissue water content that can intensify the formation of reactive oxygen species (ROS) [10]. 
In recent years, biochemical mechanisms related to dormancy and budburst in different regions and plant species such as walnut [11], apricot [12], apple [13], grapevine [14], and figs [15] have been reported. All these studies describe changes in the activity of antioxidant enzymes (CAT and APX), sugar and starch content, and endogenous hormones such as $\mathrm{GA}_{3}$.

To eliminate ROS and minimise oxidative damage, grapevines have an effective antioxidant control system, involving nonenzymatic antioxidants and enzymic antioxidants that protect cellular structures, neutralising and/or removing free radicals and converting them into less reactive species [16,17]. Proline plays an important role in plant response to abiotic stress since it contributes to cellular osmotic adjustment, removal of ROS, protection of membrane integrity, and stabilisation of enzymes and proteins [18-20]. Carbohydrates stored during the previous growing season constitute sources of energy for metabolic activity during dormancy and budburst. Soluble sugars are also important for the osmotic properties of buds and for conferring freezing tolerance, as they are essential for their winter survival [21]. In winter, starch is the main reserve of carbohydrates, but during spring, part of the starch reserves is hydrolysed into soluble sugars, providing energy for buds' growth and development. At this stage, consumption of soluble sugars increases due to increased respiration rates and metabolic activity [22,23].

The endogenous gibberellins (GAs) regulate several aspects of plant growth and development processes, including seed germination, cell division and elongation, and floral induction [24]. Among the classes of gibberellins biologically active in breaking dormancy is gibberellic acid $\left(\mathrm{GA}_{3}\right)$. Physiological and transcriptomic studies showed the involvement of endogenous GA in regulating and breaking dormancy in different perennial species-namely, sweet cherry [25], grapevine [26], and the Japanese apricot [27].

An irregular and variable budburst is a significant obstacle to normal bud development, with a potentially severe impact on bud fruitfulness that can result in substantial yield losses due to decreased bunch number. Alvarinho, Fernão-Pires, and Loureiro are three of the most relevant white grapevine varieties for wine production in the Vinhos Verdes Demarcated Region, VVDR (Portugal's prominent wine appellation). Despite their importance for the region, to date, no research has been developed on biochemical and physiological processes that occur in buds. Consequently, there is a need for better understanding and knowledge about the underlying biochemical changes in the buds, to allow improved vineyard management (e.g., bud load adjustment), particularly in the scenario of climate change [28]. To this end, this study aimed to investigate changes in antioxidant enzymatic activity, MDA, proline, $\mathrm{GA}_{3}$, and carbohydrate content in buds during dormancy and budburst of these varieties from two vineyards of the VVDR.

\section{Materials and Methods}

\subsection{Plant Material and Growth Conditions}

The plant material was collected in two commercial vineyards, located in Celorico de Basto $\left(41^{\circ} 25^{\prime} 15^{\prime \prime}\right.$ N, $7^{\circ} 58^{\prime} 10^{\prime \prime}$ W, 243 m, Sub-Region of Basto) and Penafiel $\left(41^{\circ} 12^{\prime} 24^{\prime \prime} \mathrm{N}\right.$ $8^{\circ} 17^{\prime} 56^{\prime \prime}$ W, $199 \mathrm{~m}$, Sub-Region of Sousa) in the VVDR, NW Portugal (Figure 1). The region has a warm temperature climate with warm and dry summer (Csb), according to the Köppen-Geiger climate classification. The soil at Celorico de Basto is classified as umbric leptosol, while at Penafiel is cumulic anthrosol [29].

After leaf fall (late October 2017), canes, with two retained buds, were randomly removed from 1-year-old wood of three Vitis vinifera L. white varieties-Alvarinho, Loureiro, and Fernão-Pires. These varieties are recognised for their adaptability to local edaphoclimatic conditions and high oenological potential for the production of 'Vinho Verde', distinguished by its aromatic, acidity, and flavour characteristics. The former two varieties are also extensively grown in NW Spain. 


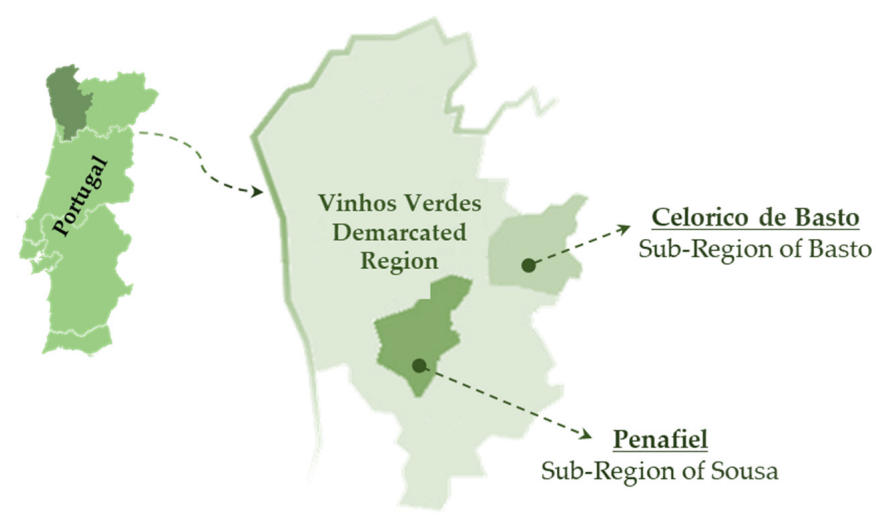

Figure 1. Map of the Vinhos Verdes Demarcated Region (NW Portugal), illustrating the Sub-Region of Sousa (vineyard of Penafiel) and Sub-Region of Basto (vineyard of Celorico de Basto).

All grapevines were grafted onto 110 Richter rootstocks and trained to a vertical shoot position on a bilateral cordon with 20 to 24 buds per vine at winter pruning. Both vineyards were managed according to the company's commercial cultural practices.

Each set of 30 canes, per variety and vineyard, was placed in plastic bags with relative humidity close to saturation and exposed for 30 days at low temperatures $\left(4^{\circ} \mathrm{C}\right)$, for chilling accumulation to break dormancy. After the chilling period, the first two dormant buds of 15 canes (phenological stage A, Baggiollini scale, 1952) were collected, frozen in liquid nitrogen, and stored at $-80^{\circ} \mathrm{C}$ for further biochemical analysis. The remaining 15 canes (with the first two dormant buds) were planted in a polypropylene seedling tray $(42 \times 7 \times 30 \mathrm{~mm})$ containing a mixture (3:1) of peat (SiroTurfa, Siro, Mira, Portugal) and pearlite (Perlite Gramoflor premium 2-6 mm, Gramoflor GmbH \& Co., Vechta, Germany). The trays were placed in a walk-in growth chamber (FitoClima 10,000 EHHF, Aralab, Rio de Mouro, Portugal) for 15 days to force budburst. During this period, the chamber environmental conditions were: temperature $=25^{\circ} \mathrm{C} / 18{ }^{\circ} \mathrm{C}$ (day/night), photoperiod $=16 \mathrm{~h}$, relative humidity $=60 \%$, and a photosynthetic photon flux density $=300 \mu \mathrm{mol} \mathrm{m}^{-2} \mathrm{~s}^{-1}$. The canes were irrigated twice a week, up to field capacity, using tap water.

When the buds reached the phenological stage C (Baggiollini scale, 1952), the budburst percentage was calculated, according to the following equation: Budburst $(\%)=(($ number of burst buds) $/$ (total number of buds) $) \times 100$. The buds were then collected, immediately frozen in liquid nitrogen, and then stored at $-80^{\circ} \mathrm{C}$ for further biochemical analysis.

\subsection{Biochemical Determinations}

\subsubsection{Preparation of Extracts}

Buds $(500 \mathrm{mg}$ ) were previously ground into a fine powder in liquid nitrogen using a chilled mortar and pestle and then homogenised in $8 \mathrm{~mL}$ extraction buffer $(50 \mathrm{mM}$ potassium phosphate buffer, $\mathrm{pH}=7.8$, containing $2 \mathrm{mM}$ EDTA). The extracts were heated at $48^{\circ} \mathrm{C}$ for $15 \mathrm{~min}$ and then centrifuged $(4000 \mathrm{rpm})$ at $4{ }^{\circ} \mathrm{C}$ for $15 \mathrm{~min}$. The supernatant was transferred into new tubes and stored at $-20^{\circ} \mathrm{C}$ for quantification of protein, malondialdehyde, and proline contents. The antioxidant enzymatic activity of bud extracts was also measured. Each analysis was performed in triplicate and determined against blank in 96-well microplates (Costar 3590, Corning, New York, USA).

\section{Malondialdehyde Content}

The level of lipid peroxidation was determined through the quantification of malondialdehyde (MDA). MDA content was measured by its reaction with thiobarbituric acid (TBA), following the procedure proposed by Ali et al. [30]. Then, $200 \mu \mathrm{L}$ of the extract was added to $500 \mu \mathrm{L}$ of $0.25 \%$ TBA in $10 \%$ of Trichloroacetic acid. The reaction mixture was heated at $100{ }^{\circ} \mathrm{C}$ for $30 \mathrm{~min}$ and then cooled in an ice bath. After centrifugation at $4000 \mathrm{rpm}$ for $15 \mathrm{~min}$, the absorbance of the supernatants was measured at 532 and $600 \mathrm{~nm}$. MDA was 
calculated by subtracting the absorbance (A532-A600) and using the extinction coefficient of $155 \mathrm{mM}^{-1} \mathrm{~cm}^{-1}$. The results were expressed as $\mu \mathrm{g} \mathrm{g}^{-1}$ of fresh weight (FW).

\section{Proline Content}

Proline content was determined according to Ábrahám et al. [31]. In summary, $200 \mu \mathrm{L}$ of the extract was added to $100 \mu \mathrm{L}$ of $3 \%$ sulfosalicylic acid, $200 \mu \mathrm{L}$ glacial acetic acid, and $2.5 \%$ acid ninhydrin solution. The mixture was heated at $96{ }^{\circ} \mathrm{C}$ for $60 \mathrm{~min}$ and then cooled in an ice bath. The absorbance values were recorded at $520 \mathrm{~nm}$. A standard calibration curve prepared with proline was performed and the results were expressed as $\mathrm{mg} \mathrm{g}^{-1}$ of FW.

\section{Total Protein Content}

The total protein content of the extract was quantified according to the method referred by Lowry et al. [32], using bovine serum albumin (BSA) as standard. Two solutions were prepared: solution A (50 mL of $2 \%$ sodium carbonate with $50 \mathrm{~mL}$ of $0.1 \mathrm{~N} \mathrm{NaOH})$ and solution $\mathrm{B}(10 \mathrm{~mL}$ of $1.56 \%$ copper sulphate with $10 \mathrm{~mL}$ of $2.37 \%$ sodium potassium tartrate). Finally, $2 \mathrm{~mL}$ of solution B was added to $100 \mathrm{~mL}$ solution A and designed as the working solution. Then, the $0.4 \mathrm{~mL}$ of sample was mixed with $4 \mathrm{~mL}$ of working solution and $0.4 \mathrm{~mL}$ of $1 \mathrm{~N}$ Folin-Ciocalteu. The reaction mixture was incubated in the dark, at room temperature, for $30 \mathrm{~min}$. The absorbance was measured at $660 \mathrm{~nm}$, and the protein content was calculated from a BSA standard calibration curve and expressed as $\mathrm{mg} \mathrm{g}^{-1} \mathrm{FW}$.

\subsubsection{Antioxidant Enzyme Activities}

Ascorbate Peroxidase Activity

The activity of ascorbate peroxidase (APX) was assayed according to Amako et al. [33]. The reaction mixture contained $50 \mathrm{mM}$ phosphate buffer $(\mathrm{pH}=7.0), 0.25 \mathrm{mM}$ ascorbic acid, and $10 \mu \mathrm{L}$ of enzyme extract. The reaction was initiated by adding $5 \mu \mathrm{L}$ of $200 \mathrm{mM}$ hydrogen peroxide $\left(\mathrm{H}_{2} \mathrm{O}_{2}\right)$ to $185 \mu \mathrm{L}$ of the reaction mixture. Absorbance was measured and monitored by oxidation of NADPH at $290 \mathrm{~nm}$ for $3 \mathrm{~min}$. The APX activity was calculated using the molar extinction coefficient for ascorbate $\varepsilon=2.8 \mathrm{mM}^{-1} \mathrm{~cm}^{-1}$, and the results were expressed as enzyme units $(\mathrm{U}) \mathrm{mg}^{-1}$ of protein.

\section{Peroxidase Activity}

The peroxidase (POX) activity was determined as oxidation of guaiacol according to the method of Maehly and Chance [34], with some modifications. The reaction mixture consisted of $200 \mu \mathrm{L}$ of $8 \mathrm{mM}$ guaiacol in $50 \mathrm{mM}$ potassium phosphate buffer $(\mathrm{pH}=7.0)$ and $50 \mu \mathrm{L}$ of enzyme extract. The reaction was initiated by adding $50 \mu \mathrm{L}$ of $1 \% \mathrm{H}_{2} \mathrm{O}_{2}$ and enzymatic activity was detected by measuring the increase in absorbance at $430 \mathrm{~nm}$ for 5 min. POX activity was calculated using the extinction coefficient $\varepsilon=6.39 \mathrm{mM}^{-1} \mathrm{~cm}^{-1}$ and expressed as enzyme units $(\mathrm{U}) \mathrm{mg}^{-1}$ of protein.

\section{Catalase Activity}

Catalase (CAT) activity was measured according to the method described by Aebi [35]. The reaction mixture consisted of $10 \mu \mathrm{L}$ enzyme extract and $50 \mathrm{mM}$ potassium phosphate buffer $(\mathrm{pH}=7.0)$. The reaction was initiated by the addition of $100 \mu \mathrm{L}$ of $3 \% \mathrm{H}_{2} \mathrm{O}_{2}$. The decrease in $\mathrm{H}_{2} \mathrm{O}_{2}$ was monitored at $240 \mathrm{~nm}$ for $3 \mathrm{~min}$. The activity of CAT was calculated using the extinction coefficient $\varepsilon=43.6 \mathrm{mM}^{-1} \mathrm{~cm}^{-1}$ and expressed as enzyme units (U) $\mathrm{mg}^{-1}$ of protein.

\section{Glutathione-S-Transferase Activity}

The activity of Glutathione-S-Transferase (GST) was assayed by the procedure of Habig et al. [36]. GST activity was measured by adding $10 \mu \mathrm{L}$ enzyme extract, $50 \mathrm{mM}$ potassium phosphate buffer $(\mathrm{pH}=7.0), 1 \mathrm{mM}$ of glutathione $(\mathrm{GSH})$, and $1 \mathrm{mM}$ of CDNB (1-chloro-2,4-dinitrobenzene). The absorbance was measured at $340 \mathrm{~nm}$, immediately and 
after $2 \mathrm{~min}$. The enzyme activity of GST was calculated using the extinction coefficient $\varepsilon=9.6 \mathrm{mM}^{-1} \mathrm{~cm}^{-1}$ and expressed as enzyme units $(\mathrm{U}) \mathrm{mg}^{-1}$ of protein.

\section{Superoxide Dismutase Activity}

The method described by Banowetz et al. [37] was used to measure the superoxide dismutase (SOD) activity. Briefly, reaction mixture $(125 \mu \mathrm{L})$ contained $0.4 \mathrm{mM}$ odianisidine, $0.5 \mathrm{mM}$ DTPA, $26 \mu \mathrm{M}$ riboflavin, $10 \mathrm{mM}$ Piperazine- $\mathrm{N}, \mathrm{N}^{\prime}$-bis (2-ethanesulfonic acid) $(\mathrm{pH}=7.5)$, and $20 \mu \mathrm{L}$ of enzyme extract. The absorbance at $450 \mathrm{~nm}$ was read initially and $30 \mathrm{~min}$ after the reaction had been irradiated with fluorescent light $(120 \mathrm{~W})$. The SOD activity was determined using a SOD standard calibration curve. The results were expressed as enzyme units $(\mathrm{U}) \mathrm{mg}^{-1}$ of protein.

\subsection{Soluble Sugars and Starch Content}

Total soluble sugars (TSS) and starch content were determined using the anthrone method adopted by $\mathrm{Ni}$ et al. [38]. Approximately $40 \mathrm{mg}$ of bud samples were previously ground to a fine powder in liquid nitrogen using a chilled mortar and pestle and homogenised with $2 \mathrm{~mL}$ pure acetone for $5 \mathrm{~min}$. After centrifugation at $1100 \mathrm{rpm}$ at $4{ }^{\circ} \mathrm{C}$ for $10 \mathrm{~min}, 80 \%$ ethanol was added to the pellets. The extract was incubated at $80{ }^{\circ} \mathrm{C}$ for $10 \mathrm{~min}$ in a water bath and again centrifuged at $1100 \mathrm{rpm}$ at $4{ }^{\circ} \mathrm{C}$ for $10 \mathrm{~min}$. The residues remaining in the tubes were stored for starch analysis. Regarding the total soluble sugar quantification, $100 \mu \mathrm{L}$ supernatants were added to $500 \mu \mathrm{L}$ of $0.2 \%$ anthrone reagent (Merck, EUA) and then placed at $100{ }^{\circ} \mathrm{C}$ for $10 \mathrm{~min}$. The absorbance was measured at $630 \mathrm{~nm}$, and total soluble sugar content was calculated using a glucose standard calibration curve and expressed as $\mathrm{mg} \mathrm{g}^{-1} \mathrm{FW}$.

The starch content was determined on the solid fraction from the above extraction by heating the pellet in $1.1 \% \mathrm{HCl}$ at $100{ }^{\circ} \mathrm{C}$ for $30 \mathrm{~min}$. Afterwards, $100 \mu \mathrm{L}$ of supernatant was added to $500 \mu \mathrm{L}$ of $0.2 \%$ anthrone reagent and then placed at $100{ }^{\circ} \mathrm{C}$ for $10 \mathrm{~min}$. The absorbance was measured at $630 \mathrm{~nm}$; the starch content was calculated based on a glucose standard calibration curve, and the results were expressed as $\mathrm{mg} \mathrm{g}^{-1} \mathrm{FW}$.

\subsection{Gibberellic Acid Content}

The endogenous gibberellic acid $\left(\mathrm{GA}_{3}\right)$ was assessed according to the method described by Ergün et al. [39] and Berríos [40]. Buds $(60 \mathrm{mg})$ were previously ground to a fine powder in liquid nitrogen using a chilled mortar and pestle and then homogenised with $1 \mathrm{~mL}$ pure ethyl acetate and $200 \mu \mathrm{L}$ pure $\mathrm{HCl}$ and stored at $-20^{\circ} \mathrm{C}$ for $24 \mathrm{~h}$. The next day, the mixture was centrifuged at $5000 \mathrm{rpm}$ for $15 \mathrm{~min}$, and the supernatants were transferred to a clean tube. The same procedure was repeated for the pellet. The combined extract (1:1) was mixed with $3 \mathrm{~mL}$ of pure ethanol and $8 \mathrm{~mL}$ of $\mathrm{HCl} 3.75 \mathrm{M}$. The absorbance was measured at $254 \mathrm{~nm}$, and the gibberellic acid was used as standard. The values were expressed as $\mu \mathrm{g} \mathrm{g}^{-1} \mathrm{FW}$.

\subsection{Statistical Analysis}

Statistical analysis was performed using JMP version 7 statistical software (SAS Institute Inc., Cary, NC, USA). The effects of the site (vineyard), variety, and phenological stage on all biochemical parameters were evaluated using a three-way factorial ANOVA. A two-way ANOVA was also used to examine the effects of site and variety on the budburst percentage. All datasets satisfied the ANOVA assumptions-namely, homogeneity of variances and normality. When the differences were significant $(p<0.05)$, Tukey's post hoc test was carried out.

\section{Results}

\subsection{Percentage of Budburst}

The results of the budburst percentage under forced conditions are presented in Table 1. Neither site (vineyard) nor variety had a significant effect $(p>0.05)$ on budburst percentage. 
However, the interaction effects of site and variety were significant $(p<0.05)$ for this variable. The Fernão-Pires variety presented, in both vineyards, the higher number of budbursts, representing a budburst percentage of $70.0 \%$ and $69.4 \%$ in Celorico de Basto and Penafiel, respectively. In contrast, the percentage of budburst was significantly lower in the Loureiro variety, especially in Celorico de Basto, where it reached $46.7 \%$ of budburst.

Table 1. Mean values of budburst percentage of Alvarinho (AL), Fernão-Pires (FP), and Loureiro (LO) varieties in Celorico de Basto and Penafiel vineyards obtained by forced bursting. The mean values followed by different letters are significantly different at $p<0.05$ by Tukey's HSD test. Different letters in the same column indicate significant differences. Site $(\mathrm{S})$, variety $(\mathrm{V})$, and interaction effects $(\mathrm{S} \times \mathrm{V})$.

\begin{tabular}{ccc}
\hline Site (S) & Variety (V) & Budburst (\%) \\
\hline \multirow{2}{*}{ Celorico de Basto } & AL & $63.3 \pm 9.7 \mathrm{ab}$ \\
& FP & $70.0 \pm 10.7 \mathrm{a}$ \\
Penafiel & LO & $46.7 \pm 8.7 \mathrm{~b}$ \\
& AL & $58.9 \pm 16.9 \mathrm{~b}$ \\
p-value & FP & $69.4 \pm 11.8 \mathrm{a}$ \\
& LO & $55.3 \pm 11.3 \mathrm{~b}$ \\
& $\mathrm{~S}$ & $\mathrm{~ns}$ \\
\end{tabular}

Symbols 'ns' indicates non-significant differences ( $p>0.05)$, and ${ }^{*} p<0.05$.

\subsection{Malondialdehyde and Proline Contents}

The effect of site $(p<0.001)$, variety $(p<0.001)$, and the phenological stage $(p<0.001)$, as well as the interactions of variety $\times$ phenological stage $(p<0.05)$ and site $\times$ variety $\times$ phenological stage $(p<0.05)$, were statistically significant on the MDA content (Table 2$)$. Between varieties, Loureiro and Alvarinho exhibited higher MDA content, with values ranging from 0.0018 to $0.0023 \mu \mathrm{g} \mathrm{g}^{-1}$ and from 0.0018 to $0.0022 \mu \mathrm{g} \mathrm{g}^{-1}$, respectively (Figure 2a). In all varieties, the MDA content increased from dormancy to budburst and was more substantial in the Loureiro variety from Penafiel, with values ranging from 0.0019 to $0.0026 \mu \mathrm{g} \mathrm{g}^{-1}$. In turn, the Fernão-Pires variety presented the lowest increase $\left(0.0018 \mu \mathrm{g} \mathrm{g}^{-1}\right)$ when compared with Alvarinho $\left(0.0021 \mu \mathrm{g} \mathrm{g}^{-1}\right)$ and Loureiro varieties $\left(0.0021 \mu \mathrm{g} \mathrm{g}^{-1}\right)$.

Table 2. Significance of site $(\mathrm{S})$, variety $(\mathrm{V})$, phenological stage $(\mathrm{P})$ and interaction effects $(\mathrm{S} \times \mathrm{V} ; \mathrm{S} \times$ $\mathrm{P} ; \mathrm{V} \times \mathrm{P} ; \mathrm{S} \times \mathrm{V} \times \mathrm{P}$ ) on MDA, proline, antioxidant enzymatic activity (APX, POX, CAT, SOD, GST), nonstructural carbohydrates (TSS and starch), and $\mathrm{GA}_{3}$, according to repeated-measures ANOVA. The values are significantly different at $p<0.05$ by Tukey's HSD test.

\begin{tabular}{|c|c|c|c|c|c|c|c|}
\hline & $\mathrm{s}$ & $\mathrm{V}$ & $\mathbf{P}$ & $\mathbf{S} \times \mathbf{V}$ & $\mathbf{S} \times \mathbf{P}$ & $\mathbf{V} \times \mathbf{P}$ & $\mathbf{S} \times \mathbf{V} \times \mathbf{P}$ \\
\hline $\operatorname{MDA}\left(\mu \mathrm{g} \mathrm{g}^{-1}\right)$ & $<0.001$ & $<0.001$ & $<0.001$ & 0.423 & 0.295 & 0.010 & 0.001 \\
\hline Proline $\left(\mathrm{mg} \mathrm{g}^{-1}\right)$ & $<0.001$ & $<0.001$ & $<0.001$ & $<0.001$ & 0.651 & $<0.001$ & 0.023 \\
\hline $\mathrm{APX}\left((\mathrm{U}) \mathrm{mg}^{-1}\right.$ of protein) & $<0.001$ & $<0.001$ & $<0.001$ & $<0.001$ & 0.021 & $<0.001$ & $<0.001$ \\
\hline POX ((U) mg ${ }^{-1}$ of protein) & $<0.001$ & 0.008 & $<0.001$ & $<0.001$ & 0.029 & $<0.001$ & $<0.001$ \\
\hline CAT ((U) $\mathrm{mg}^{-1}$ of protein) & 0.704 & 0.280 & $<0.001$ & 0.009 & 0.002 & 0.584 & $<0.001$ \\
\hline $\mathrm{SOD}\left((\mathrm{U}) \mathrm{mg}^{-1}\right.$ of protein) & $<0.001$ & $<0.001$ & $<0.001$ & $<0.001$ & 0.375 & $<0.001$ & $<0.001$ \\
\hline GST ((U) $\mathrm{mg}^{-1}$ of protein) & $<0.001$ & $<0.001$ & $<0.001$ & $<0.001$ & $<0.001$ & 0.763 & 0.500 \\
\hline TSS $\left(\mathrm{mg} \mathrm{g}^{-1}\right)$ & $<0.001$ & $<0.001$ & $<0.001$ & $<0.001$ & 0.001 & 0.022 & $<0.001$ \\
\hline Starch $\left(\mathrm{mg} \mathrm{g}^{-1}\right)$ & $<0.001$ & $<0.001$ & $<0.001$ & 0.001 & 0.716 & 0.009 & $<0.001$ \\
\hline $\mathrm{GA}_{3}\left(\mu \mathrm{g} \mathrm{g}^{-1} \mathrm{FW}\right)$ & 0.136 & $<0.001$ & $<0.001$ & $<0.001$ & 0.013 & $<0.001$ & 0.039 \\
\hline
\end{tabular}


(a)

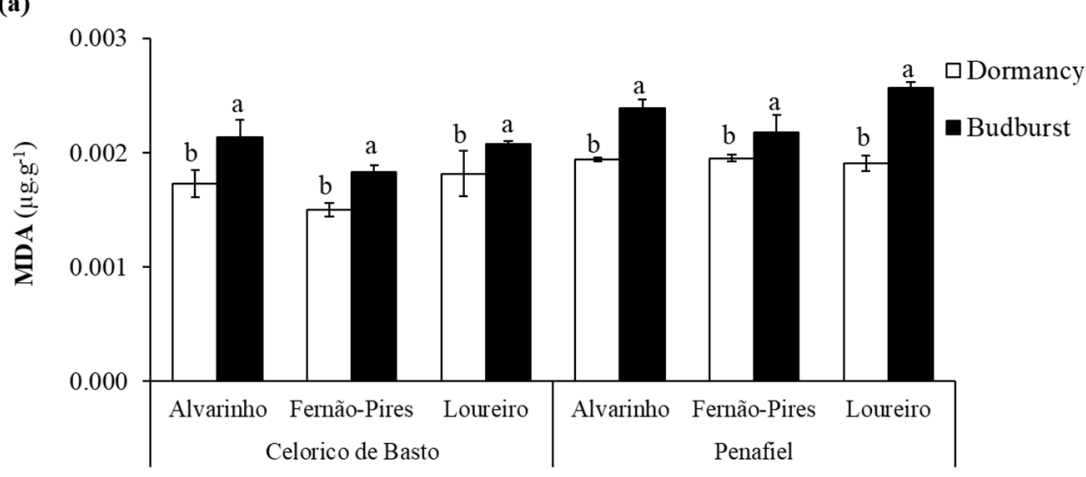

(b)

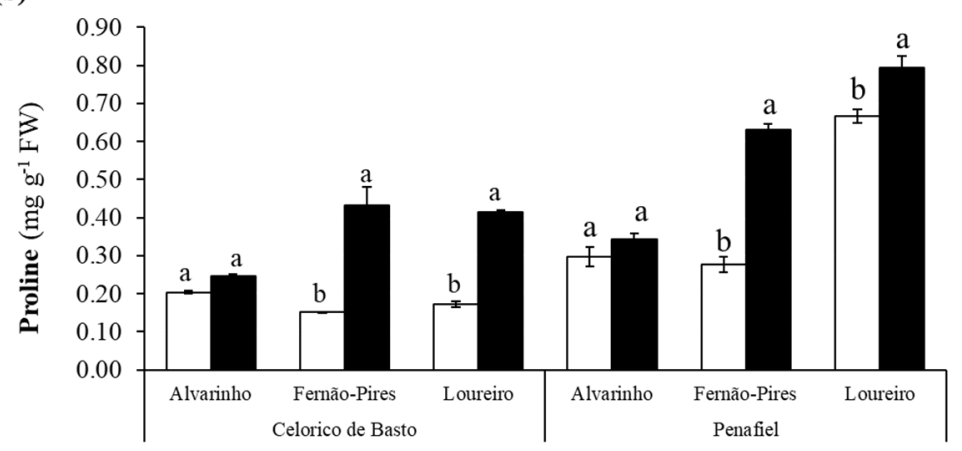

Figure 2. Malondialdehyde (MDA) content (a) and proline content (b) at dormancy and budburst for Alvarinho, Fernão-Pires, and Loureiro buds from Celorico de Basto and Penafiel vineyards. The columns represent the mean values and the bars the respective standard error of three replicates. Different letters indicate significant differences between phenological stages $(p<0.05)$.

A significant effect of site $(p<0.001)$, variety $(p<0.001)$, and phenological stage $(p<0.001)$ on proline content was observed (Table 2$)$. Regarding interactions, only the effect of site $x$ phenological stage was not significant $(p>0.05)$. The higher levels of this amino acid were recorded at budburst (Figure 2b). Except for Alvarinho, there was a significant increase in the proline content between dormancy and budburst, by $56-64 \%$ in Fernão-Pires and $16-53 \%$ in Loureiro, respectively (Figure 2). Between varieties, the proline content tended to be higher in Loureiro $\left(0.51 \mathrm{mg} \mathrm{g}^{-1}\right)$ when compared with Fernão-Pires $\left(0.37 \mathrm{mg} \mathrm{g}^{-1}\right)$ and Alvarinho $\left(0.27 \mathrm{mg} \mathrm{g}^{-1}\right)$.

\subsection{Enzyme Antioxidant Activity}

The activities of almost all antioxidant enzymes were significantly influenced by site, variety, phenological stage, and the interaction among these factors (Table 2). The results revealed that the activities of APX, POX and SOD depend on phenological stage and variety (interaction effects of variety $\times$ phenological stage were all statistically significant, Table 2). In addition, significant interactions between site and variety were observed for $\operatorname{APX}(p<0.001)$, POX $(p<0.001)$, SOD $(p<0.001)$, GST $(p<0.001)$, and CAT $(p<0.001)$ activities. Furthermore, there were significant differences between varieties and phenological stages for APX $(p<0.001)$, POX $(p<0.001)$, and SOD $(p<0.001)$ activities. Significant interactions among site, variety, and phenological stage $(p<0.001)$ for enzyme activities were also found. In general, the activity of the enzymes was higher in Celorico de Basto than in Penafiel, except for CAT, whose activity remained similar in both sites. Fernão-Pires presented significantly higher APX, POX activities, followed by Loureiro and Alvarinho. In turn, Alvarinho showed the higher SOD activity, followed by Fernão-Pires and Loureiro. With respect to phenology, APX, POX, and SOD activities were higher at dormancy, while CAT showed higher activity at budburst (Figure 3). 

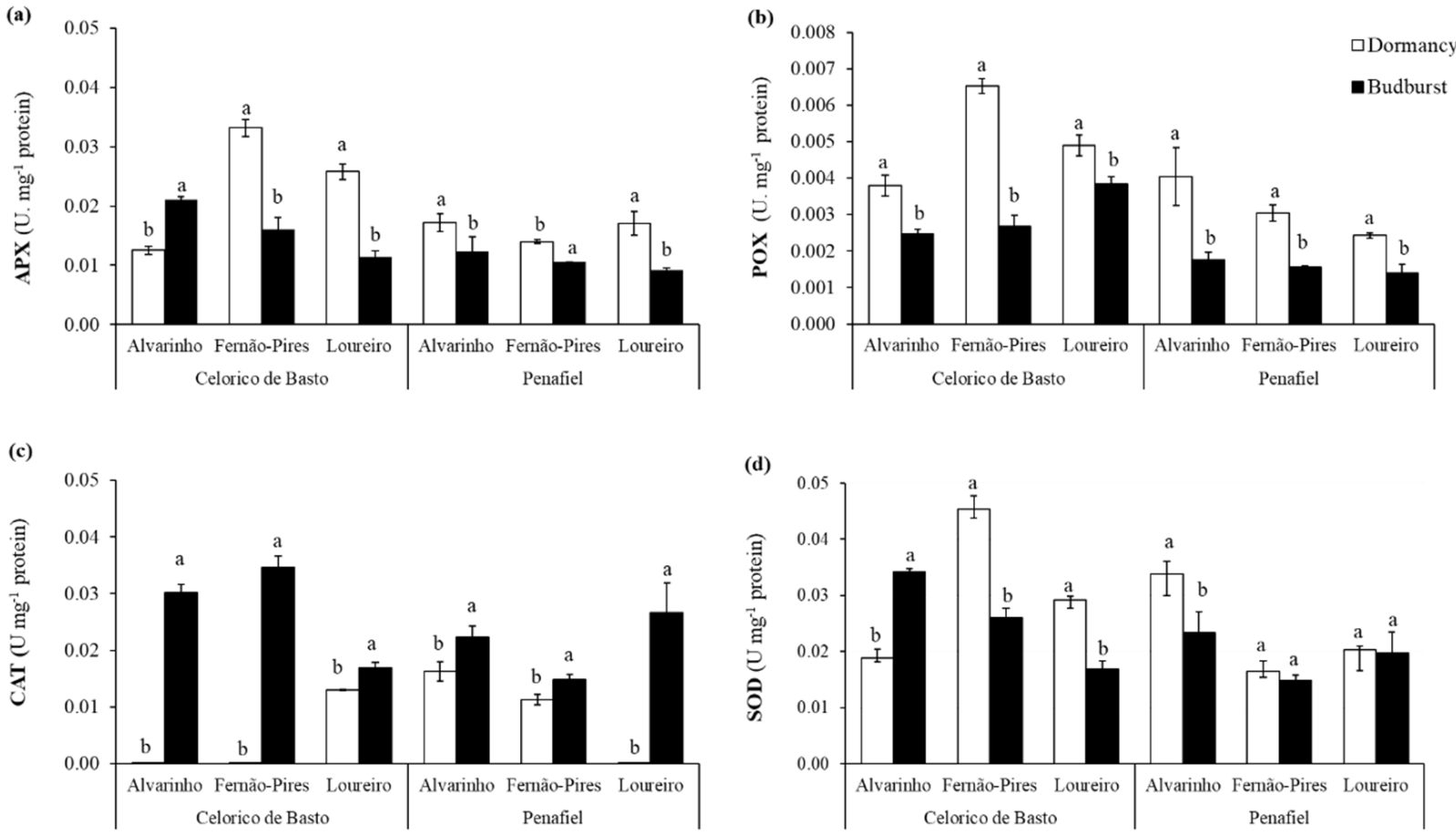

Figure 3. Enzymatic activity of ascorbate peroxidase (APX) (a), peroxidase (POX) (b), catalase (CAT) (c), superoxide dismutase (SOD) (d) in two phenological stages (dormancy and budburst) in Alvarinho, Fernão-Pires, and Loureiro buds from Celorico de Basto and Penafiel sites. The columns represent the mean values and the bars the respective standard error of three replicates. Different letters indicate significant differences between phenological stages $(p<0.05)$.

For the APX activity, higher differences in enzyme activity were observed in FernãoPires from Penafiel. On the other hand, increased activity in budburst for Alvarinho from Celorico de Basto was found. Additionally, for POX, higher enzyme activity was observed in dormancy, compared with budburst. Through an analysis of Figure 3b, it is possible to verify that the Fernão-Pires variety from Celorico de Basto showed higher activity in dormant buds.

The results also revealed that the CAT activity was close to zero in dormancy for Alvarinho and Fernão-Pires (from Celorico de Basto) and Loureiro (from Penafiel). However, significantly higher enzyme activity was observed during budburst, particularly for Fernão-Pires from Celorico de Basto. The SOD activity was generally significantly higher in dormancy. However, Alvarinho from Celorico de Basto presented a higher activity of this enzyme at budburst. In addition, the GST activity was significantly higher at budburst, particularly for the Alvarinho and Loureiro varieties, both from Celorico de Basto (not shown), though with very low values $(<0.001)$ for all varieties and sites.

\subsection{Soluble Sugars and Starch}

Soluble sugars (TSS) content was significantly influenced by site $(p<0.001)$, variety $(p<0.001)$, phenological stage $(p<0.001)$, and interactions between these factors (Table 2). In general, the Alvarinho variety exhibited a higher content of soluble sugars (6.18 $\mathrm{mg} \mathrm{g}^{-1} \mathrm{FW}$ ), followed by Fernão-Pires ( $5.58 \mathrm{mg} \mathrm{g}^{-1} \mathrm{FW}$ ) and Loureiro (4.59 $\mathrm{mg} \mathrm{g}^{-1} \mathrm{FW}$ ). In addition, the soluble sugars content was remarkably higher in Penafiel $\left(5.83 \mathrm{mg} \mathrm{g}^{-1} \mathrm{FW}\right)$ than in Celorico de Basto (5.07 $\left.\mathrm{mg} \mathrm{g}^{-1} \mathrm{FW}\right)$, and at budburst $\left(6.49 \mathrm{mg} \mathrm{g}^{-1} \mathrm{FW}\right)$, compared with dormancy (4.42 $\mathrm{mg} \mathrm{g}^{-1} \mathrm{FW}$ ) (Figure 4a). The only exceptions were Fernão-Pires (Celorico de Basto) and Alvarinho (Penafiel), which presented similar values in both phenological stages. 
(a)

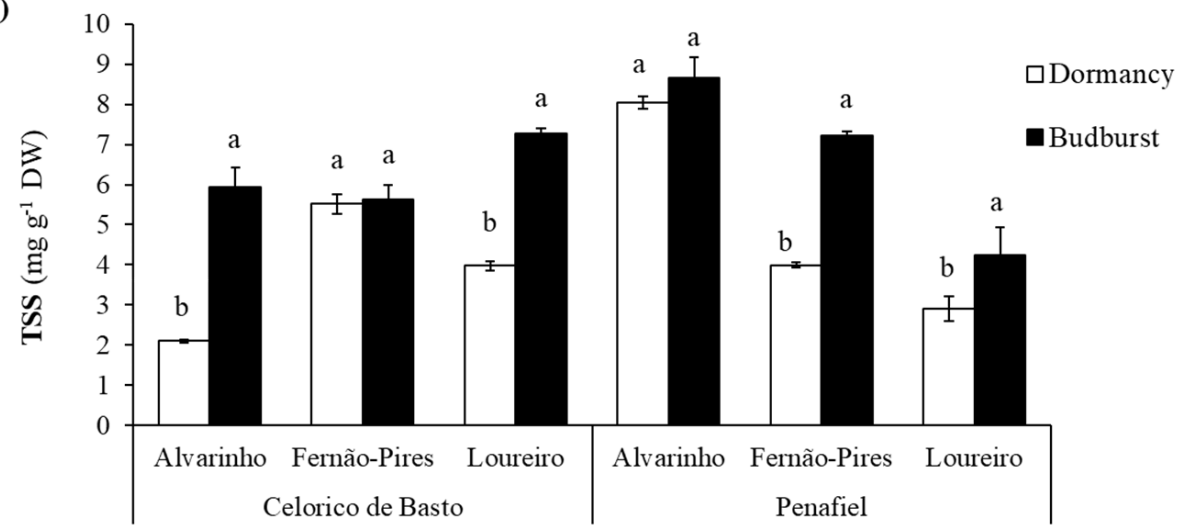

(b)

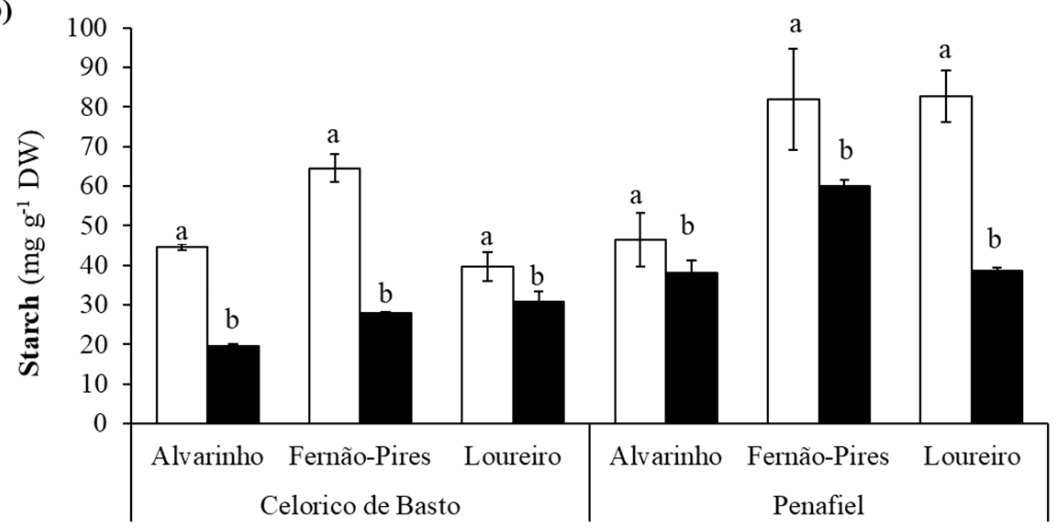

Figure 4. Total soluble sugar (TSS) (a) and starch content (b) at dormancy and budburst for Alvarinho, Fernão-Pires, and Loureiro buds from Celorico de Basto and Penafiel sites. The columns represent the mean values and the bars the respective standard error of three replicates. Different letters indicate significant differences between phenological stages $(p<0.05)$.

The starch content also varied between site $(p<0.001)$, variety $(p<0.001)$ and phenological stage $(p<0.001)$ and interactions, with an exception for site $\times$ phenological stage interaction (Table 2). The values recorded from Penafiel $\left(57.97 \mathrm{mg} \mathrm{g}^{-1} \mathrm{FW}\right)$ were statistically higher, compared with Celorico de Basto ( $\left.37.83 \mathrm{mg} \mathrm{g}^{-1} \mathrm{FW}\right)$, Figure $4 \mathrm{~b}$. Regarding varieties, the starch content was higher in Fernão-Pires (58.6 $\mathrm{mg} \mathrm{g}^{-1} \mathrm{FW}$ ) and lower in Alvarinho, with $37.2 \mathrm{mg} \mathrm{g}^{-1} \mathrm{FW}$. There was a considerable decrease in the starch content between dormancy (59.94 $\left.\mathrm{mg} \mathrm{g}^{-1} \mathrm{FW}\right)$ and budburst $\left(35.86 \mathrm{mg} \mathrm{g}^{-1} \mathrm{FW}\right)$, with the reduction (about $56 \%$ ) more pronounced for Fernão-Pires and Alvarinho varieties, both from Celorico de Basto.

\subsection{Gibberellic Acid Content}

Significant differences between varieties $(p<0.001)$ and phenological stages $(p<0.001)$ were found in the gibberellic acid $\left(\mathrm{GA}_{3}\right)$ concentration (Table 2). $\mathrm{GA}_{3}$ was significantly higher in Alvarinho (1.14 $\left.\mathrm{mg} \mathrm{g}^{-1} \mathrm{FW}\right)$ and lower in Fernão-Pires variety $\left(0.84 \mathrm{mg} \mathrm{g}^{-1} \mathrm{FW}\right)$ (Figure 5). Significant differences between phenological stages $(p<0.001)$ were also found, with the most significant increase in the $\mathrm{GA}_{3}$ content at budburst. A higher increment in $\mathrm{GA}_{3}$ content from dormancy to budburst was observed in the Loureiro variety from Celorico de Basto and Alvarinho and Loureiro from Penafiel, with an increase of $12 \%$, $11 \%$, and $17 \%$, respectively. There was, however, no significant difference in this hormone between the phenological stages for Alvarinho from Celorico de Basto. 


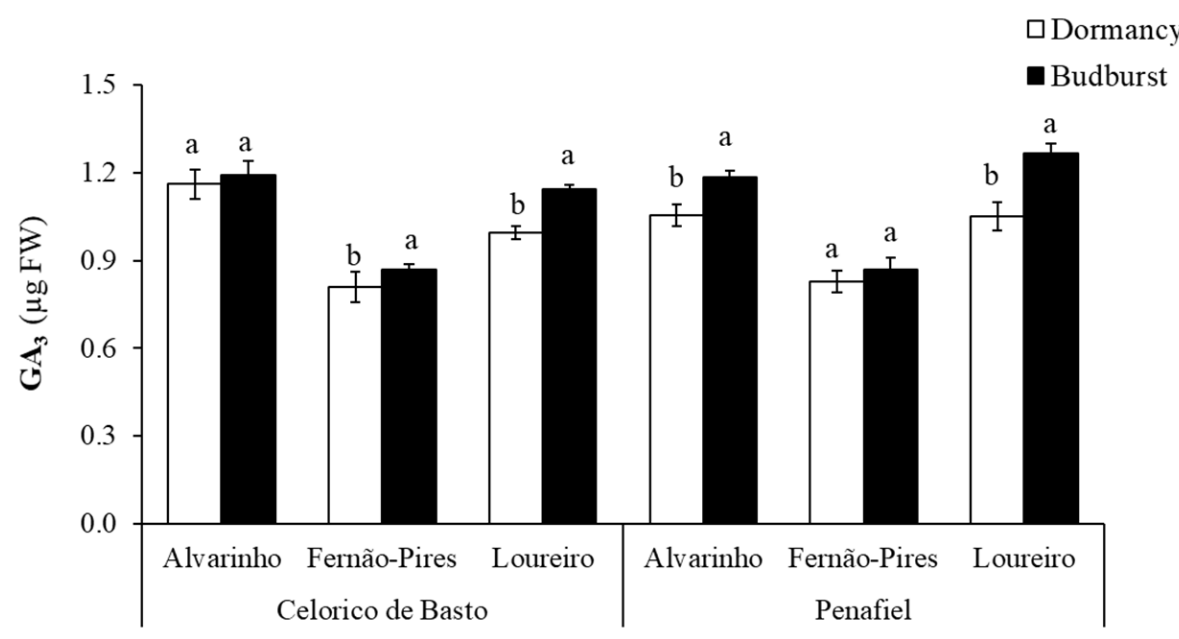

Figure 5. Gibberellic acid $\left(\mathrm{GA}_{3}\right)$ content at dormancy and budburst for Alvarinho, Fernão-Pires and Loureiro buds from Celorico de Basto and Penafiel sites. The columns represent the mean values and the bars the respective standard error of three replicates. Different letters indicate significant differences between phenological stages $(p<0.05)$.

\section{Discussion}

Dormancy and budburst involve a set of physiological, biochemical, and metabolic changes that are indispensable for the survival and development of grapevines [1,41]. Therefore, in this study, the biochemical changes that occur in dormant buds and forced bursting were evaluated.

The number of burst buds has a marked influence on the grapevine yield since, at this stage, the potential number of bunches is already predefined [42,43]. The budburst varied between varieties in each of the vineyards, with percentages below $50 \%$, as in the case of Loureiro in Celorico de Basto (Table 1). The budburst percentage was, however, higher for the Fernão-Pires variety (about 70\%). This relatively low percentage may be due to the simultaneous competition for carbohydrate reserves in cane between buds and adventitious root formation in the cane [44].

The biochemical analyses displayed differences between sites (vineyards) about MDA, proline, enzymatic activity, and carbohydrate content. In general, the buds from Celorico de Basto showed higher enzymatic activity (APX, SOD, POX). In turn, those from Penafiel had higher MDA and proline. Although Celorico de Basto had a warmer summer and cold winter, compared with Penafiel in 2017, it is still not clear that the edaphoclimatic conditions of each vineyard can potentiate the different biochemical responses observed in buds [45].

Regarding varieties, there was a different response for each of them, with MDA and proline content being significantly higher in Loureiro (Figure 2a,b). Fernão-Pires presented higher activities of APX and POX, while Alvarinho showed greater activity of SOD. These varietal responses may be related to the intrinsic characteristics, particularly chilling accumulation requirements and physiological responses [10,11,46]. Different enzyme activities, soluble sugars, and proline content were observed in terminal buds of three different walnut genotypes during dormancy break [11].

The three varieties showed different responses in terms of enzymatic activity regarding different sites and phenological stages (Table 2). Thus, APX, POX, and SOD activities were significantly higher during dormancy and subsequently decreased at the budburst, with different levels between varieties and vineyards. On the other hand, CAT activity was lower in the dormancy period and significantly increased at the budburst. These results are in agreement with studies developed in dormant buds of apple [47] and fig trees [15], where higher APX and POD activities and lower CAT activity during dormancy until bud break were observed. An increase in CAT activity occurred in the absence of SOD, indicating that SOD is not the primary enzyme for $\mathrm{H}_{2} \mathrm{O}_{2}$ formation, as noted by Abassi et al. [47]. 
A few studies have shown that oxidative stress can play an important role in bud dormancy break, as increased $\mathrm{H}_{2} \mathrm{O}_{2}$ levels in buds seem to act as a signalling molecule at this stage $[10,14]$. The increase in detoxification pathways and antioxidant defence-namely, CAT, SOD, APX enzymes, and proteins of the peroxidase family, in breaking dormancy attests that oxidative stress is an important part of the dormancy process [10]. Studies of dormancy-breaking agents' application have provided more insight into how oxidative stress induces dormancy and budburst. It has been proposed that the application of these compounds inhibits CAT activity, which induces an increase in $\mathrm{H}_{2} \mathrm{O}_{2}$ content, consequently causing oxidative stress $[2,44,48-50]$.

The results showed that despite the apparent inactivity of buds in the dormant stage, the enzymatic activity detected may indicate that, internally, a dormancy break mechanism may be occurring since buds were previously submitted to a period of low temperatures, to accumulate chilling hours. To our knowledge, there are no studies reporting values of enzyme antioxidant activity in buds of different grapevine varieties.

The lipid peroxidation of the membrane, evaluated by the formation of MDA (a secondary product of lipid peroxidation), can be considered an indicator of the cell damage caused by ROS [16,51]. In all varieties, lipid peroxidation, as indicated by MDA content, was higher at budburst, compared with dormancy. Alvarinho and Loureiro were the varieties with higher MDA values, particularly from the Penafiel site (Figure 2a).

Proline plays an important role in response to stress in plants since it contributes to cellular osmotic adjustment and removal of ROS [24]. A significant increase in proline content was observed during the budburst (Figure 2b). As noted, the effect of this increase was different between vineyards and varieties, with higher levels observed in the buds of the Loureiro and Fernão-Pires varieties from Penafiel. An increase in proline during break dormancy has been observed in perennial species, such as apple [44,52,53], Japanese apricot [27], and grapevine [2,54], treated with dormancy-breaking agents. These findings highlight the role of this amino acid, which may act as a compatible osmolyte and may have protected cellular structures against ROS; in addition, as a signalling molecule, it may have induced the events leading to break dormancy.

An increase in endogenous levels of $\mathrm{GA}_{3}$ in budburst for three varieties was found (Figure 5). Previous studies report that gibberellins are essential regulators of dormancy and bud break, meeting downregulated at the induction of dormancy and upregulated during dormancy break and budburst [24] For this reason, the increase observed may be related to vegetative growth processes, once a promoter of cell growth and elongation. Chengguo et al. [55] reported a rise in $\mathrm{GA}_{3}$ content during dormancy break and budburst in sweet cherry buds, which may be related to the decrease in ABA content in buds, with environmental temperature as a regulatory factor. However, Zheng et al. [26] reported that gibberellins have distinct functions in grapevine buds, during and after the dormancy break. According to these authors, despite the positive role of gibberellins in natural dormancy break, an exogenous application of this hormone can have inhibitory effects on the budburst.

Regarding the contents of total soluble sugars and starch, significant changes between the dormant bud and budburst of the three varieties were found. There was an increase in the total soluble sugar concentration and a concomitant decrease in starch concentration between the two phenological stages, in all varieties. In dormant buds, starch concentration was higher than that of soluble sugars, a tendency that was manifestly reversed in the budburst (Figure 4, Table 2). Studies on apple [13,52], walnut [53], and fig trees [15] observed a reduction in the starch content and a simultaneous enhancement in the total soluble sugar during endodormancy. These findings are related to the carbohydrate metabolism that occurs between dormancy, dormancy break, and budburst, as a result of cold hardiness.

Carbohydrate reserves are the main source of energy for metabolic changes that occur during dormancy and budburst until the leaves acquire photosynthetic capacity [56-59]. In addition to these functions, starch and soluble sugars availability serve as freezing protectants, leading to an enhanced freezing tolerance during winter $[53,60]$. According to 
Mohamed [41,54], during dormancy, part of the starch reserves is hydrolysed into soluble sugar, by increasing the activity of $\alpha$-amylase, an enzyme responsible for degrading starch and induced by low temperatures. Thus, a rise in the starch hydrolysis induces a soluble sugars content increase at this stage.

Low total soluble sugars and starch concentrations in the bud tissues are also one of the causes indicated for the incidence of bud necrosis and low budburst $[61,62]$. In these situations, the carbohydrate content may be insufficient to meet the energy needs required for metabolic and respiratory activities necessary to break dormancy and support plant vegetative growth $[62,63]$.

\section{Conclusions}

The buds' biochemical changes addressed in the present study are considered very important to understand the responses of grapevines, as regards the physiological and biochemical mechanisms that lead to dormancy and budburst. The comprehension of these mechanisms may contribute to improved vineyard management and reduction in wine production fluctuations over the years.

The present research indicated that MDA, proline, soluble sugars, and endogenous $\mathrm{GA}_{3}$ contents were higher during budburst, compared with dormancy. The enzymatic activity, MDA, proline, and carbohydrate content also varied between varieties and sites, which may be related to the antioxidant metabolism of each variety and climatic conditions.

The results highlight the complexity of biochemical processes/mechanisms involved in the transition from dormancy to budburst. Though the study was mainly performed under controlled environmental conditions, the methodologies and results may be applied to different varieties and wine regions (particularly Iberian regions).

In future studies, enzymatic activities in buds of different varieties should be monitored throughout dormancy until budburst under field conditions, for understanding the effects of environmental factors on this mechanism. Additionally, there is a need to identify potential biochemical markers or indicators of oxidative stress in buds at different phenological stages.

Author Contributions: Conceptualisation, A.I.M., A.C.M., and E.A.B.; data curation, A.I.M. and A.A.; funding acquisition, A.C.M.; investigation, all authors.; methodology, all authors; project administration, A.C.M.; resources, all authors; supervision, A.C.M. and E.A.B.; writing-original draft preparation, A.I.M.; writing-review and editing, all authors. All authors have read and agreed to the published version of the manuscript.

Funding: This study was funded by the INTERAC project- "Integrated Research Environmental, Agro-Chain and Technology", no. NORTE-01-0145-FEDER-000017, in its line of research entitled VitalityWine, co-financed by European Regional Development Fund (ERDF) through NORTE 2020. The study was also funded by the VITISHIDRI project-“Estratégias para a gestão do stress hídrico da vinha no Douro Superior" financially supported by the European Agricultural Fund for Rural Development and the Rural Development Programme 2020.

Institutional Review Board Statement: Not applicable.

Informed Consent Statement: Not applicable.

Data Availability Statement: Not applicable.

Acknowledgments: This work is supported by National Funds by FCT-Portuguese Foundation for Science and Technology, under the project UIDB/04033/2020. The authors acknowledge Aveleda S.A. for the collaboration in making available their vineyards for the study.

Conflicts of Interest: The authors declare no conflict of interest. The funders had no role in the design of the study; in the collection, analyses, or interpretation of data; in the writing of the manuscript, or in the decision to publish the results. 


\section{References}

1. Arora, R.; Rowland, L.; Tanino, K. Induction and Release of Bud Dormancy in Woody Perennials: A Science Comes of Age. HortScience 2003, 38, 911-921. [CrossRef]

2. Pérez, F.J.; Vergara, R.; Rubio, S. H2O2 Is Involved in the Dormancy-Breaking Effect of Hydrogen Cyanamide in Grapevine Buds. Plant Growth Regul. 2008, 55, 149-155. [CrossRef]

3. Faust, M.; Erez, A.; Rowland, L.J.; Wang, S.Y.; Norman, H.A. Bud Dormancy in Perennial Fruit Trees: Physiological Basis for Dormancy Induction, Maintenance, and Release. HortScience 1997, 623-629. [CrossRef]

4. Or, E. Grape Bud Dormancy Release-The Molecular Aspect. In Grapevine Molecular Physiology E Biotechnology, Roubelakis-Angelakis, K.A., Ed.; Springer: Dordrecht, The Netherlands, 2009; pp. 1-29. ISBN 9789048123056.

5. Carvalho, L.C.; Vidigal, P.; Amâncio, S. Oxidative Stress Homeostasis in Grapevine (Vitis vinifera L.). Front. Environ. Sci. 2015, 3 , 20. [CrossRef]

6. Lloret, A.; Badenes, M.L.; Ríos, G. Modulation of Dormancy and Growth Responses in Reproductive Buds of Temperate Trees. Front. Plant Sci. 2018, 9, 1368. [CrossRef] [PubMed]

7. Reynier, A. Manual de Viticultura; Publicações Europa-América: Sintra, Portugal, 1990.

8. Keller, M. Chapter 2-Phenology and Growth Cycle. In The Science of Grapevines, 2nd ed.; Keller, M., Ed.; Academic Press: San Diego, CA, USA, 2015; pp. 59-99. ISBN 9780124199873.

9. Magalhães, N. Tratado de Viticultura: A Videira, a Vinha e o "Terroir", 1st ed.; Esfera Poética: Lisboa, Portugal, 2015.

10. Beauvieux, R.; Wenden, B.; Dirlewanger, E. Bud Dormancy in Perennial Fruit Tree Species: A Pivotal Role for Oxidative Cues. Front. Plant Sci. 2018, 9, 657. [CrossRef]

11. Farokhzad, A.; Nobakht, S.; Alahveran, A.; Sarkhosh, A.; Mohseniazar, M. Biochemical Changes in Terminal Buds of Three Different Walnut (Juglans Regia, L.) Genotypes during Dormancy Break. Biochem. Syst. Ecol. 2018, 76, 52-57. [CrossRef]

12. Hernandez, J.A.; Díaz-Vivancos, P.; Martínez-Sánchez, G.; Alburquerque, N.; Martínez, D.; Barba-Espín, G.; Acosta-Motos, J.R.; Carrera, E.; García-Bruntón, J. Physiological and Biochemical Characterization of Bud Dormancy: Evolution of Carbohydrate and Antioxidant Metabolisms and Hormonal Profile in a Low Chill Peach Variety. Sci. Hortic. 2021, 281, 109957. [CrossRef]

13. Sapkota, S.; Liu, J.; Islam, M.T.; Sherif, S.M. Changes in Reactive Oxygen Species, Antioxidants and Carbohydrate Metabolism in Relation to Dormancy Transition and Bud Break in Apple (Malus $\times$ Domestica Borkh) Cultivars. Antioxidants 2021, $10,1549$. [CrossRef]

14. Pérez, F.J.; Lira, W. Possible Role of Catalase in Post-Dormancy Bud Break in Grapevines. J. Plant Physiol. 2005, 162, 301-308. [CrossRef]

15. Sedaghat, S.; Gaaliche, B.; Rahemi, M.; Zare, H.; Jafari, M. Enzymatic Activity and Physico-Chemical Changes of Terminal Bud in Rain-Fed Fig (Ficus carica L. 'Sabz') during Dormant Season. Hortic. Plant J. 2021, 8. in press. [CrossRef]

16. Scandalios, J.G. Oxidative Stress: Molecular Perception and Transduction of Signals Triggering Antioxidant Gene Defenses. Braz. J. Med. Biol. Res. 2005, 38, 995-1014. [CrossRef] [PubMed]

17. Sarker, U.; Oba, S. Drought Stress Enhances Nutritional and Bioactive Compounds, Phenolic Acids and Antioxidant Capacity of Amaranthus Leafy Vegetable. BMC Plant Biol. 2018, 18, 258. [CrossRef]

18. Szabados, L.; Savouré, A. Proline: A Multifunctional Amino Acid. Trends Plant Sci. 2010, 15, 89-97. [CrossRef] [PubMed]

19. Hayat, S.; Hayat, Q.; Alyemeni, M.N.; Wani, A.S.; Pichtel, J.; Ahmad, A. Role of Proline under Changing Environments. Plant Signal Behav. 2012, 7, 1456-1466. [CrossRef] [PubMed]

20. Liang, X.; Zhang, L.; Natarajan, S.; Becker, D. Proline Mechanisms of Stress Survival. Antioxid. Redox Signal. 2013, 19, 998-1011. [CrossRef] [PubMed]

21. Horikoshi, H.M.; Sekozawa, Y.; Sugaya, S. Inhibition of Carbohydrate Metabolism by Thermal Fluctuations during Endodormancy Lead to Negative Impacts on Bud Burst and Incidence of Floral Necrosis in 'Housui' Japanese Pear Flower Buds. Sci. Hortic. 2017, 224, 324-331. [CrossRef]

22. Sivaci, A. Seasonal Changes of Total Carbohydrate Contents in Three Varieties of Apple (Malus sylvestris Miller) Stem Cuttings. Sci. Hortic. 2006, 109, 234-237. [CrossRef]

23. Pagter, M.; Andersen, U.B.; Andersen, L. Winter Warming Delays Dormancy Release, Advances Budburst, Alters Carbohydrate Metabolism and Reduces Yield in a Temperate Shrub. AoB Plants 2015, 7, plv024. [CrossRef]

24. Liu, J.; Sherif, S.M. Hormonal Orchestration of Bud Dormancy Cycle in Deciduous Woody Perennials. Front. Plant Sci. 2019, 10, 1136. [CrossRef]

25. Vimont, N.; Schwarzenberg, A.; Domijan, M.; Beauvieux, R.; Arkoun, M.; Yvin, J.C.; Cortijo, S.; Wigge, P.A.; Dirlewanger, E.; Wenden, B. Hormonal Balance Finely Tuned Dormancy Status in Sweet Cherry Flower Buds. BioRxiv 2018, 4, 423871. [CrossRef]

26. Zheng, C.; Kwame Acheampong, A.; Shi, Z.; Halaly, T.; Kamiya, Y.; Ophir, R.; Galbraith, D.W.; Or, E. Distinct Gibberellin Functions during and after Grapevine Bud Dormancy Release. J. Exp. Bot. 2018, 69, 1635-1648. [CrossRef] [PubMed]

27. Zhuang, W.; Gao, Z.; Wen, L.; Huo, X.; Cai, B.; Zhang, Z. Metabolic Changes upon Flower Bud Break in Japanese Apricot Are Enhanced by Exogenous GA 4. Hortic. Res. 2015, 2, 1-10. [CrossRef] [PubMed]

28. Pellegrino, A.; Rogiers, S.; Deloire, A. Grapevine Latent Bud Dormancy and Shoot Development. IVES Tech. Rev. Vine Wine 2020. [CrossRef]

29. Agroconsultores. Geometral Carta de Solos e Carta da Aptidão da Terra de Entre-Douro e Minho, Escala 1:100,000. Peças Desenhadas e Memórias Descritivas; Agroconsultores: Lisboa, Portugal, 1995. 
30. Ali, M.B.; Hahn, E.J.; Paek, K.Y. Effects of Light Intensities on Antioxidant Enzymes and Malondialdehyde Content during Short-Term Acclimatization on Micropropagated Phalaenopsis plantlet. Environ. Exp. Bot. 2005, 54, 109-120. [CrossRef]

31. Ábrahám, E.; Hourton-Cabassa, C.; Erdei, L.; Szabados, L. Methods for Determination of Proline in Plants. In Plant Stress Tolerance: Methods and Protocols; Sunkar, R., Ed.; Humana Press: Totowa, NJ, USA, 2010; pp. 317-331. ISBN 9781607617020.

32. Lowry, O.H.; Rosebrough, N.J.; Farr, A.L.; Randall, R.J. Protein Measurement with the Folin Phenol Reagent. J. Biol. Chem. 1951, 193, 265-275. [CrossRef]

33. Amako, K.; Chen, G.X.; Asada, K. Separate Assays Specific for Ascorbate Peroxidase and Guaiacol Peroxidase and for the Chloroplastic and Cytosolic Isozymes of Ascorbate Peroxidase in Plants. Plant Cell Physiol. 1994, 35, 497-504. [CrossRef]

34. Maehly, A.C.; Chance, B. The Assay of Catalases and Peroxidases. Methods Biochem Anal 1954, 1, 357-424. [CrossRef]

35. Aebi, H. Catalase In Vitro. In Methods in Enzymology; Oxygen Radicals in Biological Systems; Academic Press: Salt Lake, UT, USA, 1984; Volume 105, pp. 121-126.

36. Habig, W.H.; Pabst, M.J.; Jakoby, W.B. Glutathione S-Transferases: The First Enzymatic Step in Mercapturic Acid Formation. J. Biol. Chem. 1974, 249, 7130-7139. [CrossRef]

37. Banowetz, G.M.; Dierksen, K.P.; Azevedo, M.D.; Stout, R. Microplate Quantification of Plant Leaf Superoxide Dismutases. Anal. Biochem. 2004, 332, 314-320. [CrossRef]

38. Ni, Z.; Kim, E.-D.; Chen, J. Protocol Exchange. 2009. Available online: https://protocolexchange.researchsquare.com/article/ nprot-521/v1 (accessed on 3 January 2022). [CrossRef]

39. Ergün, N.; Topcuoglu, S.F.; Yildiz, A. Auxin (Indole-3-Acetic Acid), Gibberellic Acid (GA3), Abscisic Acid (ABA) and Cytokinin (Zeatin) Production by Some Species of Mosses and Lichens. Turk. J. Bot. 2002, 26, 13-18.

40. Berríos, J.; Illanes, A.; Aroca, G. Spectrophotometric Method for Determining Gibberellic Acid in Fermentation Broths. Biotechnol. Lett. 2004, 26, 67-70. [CrossRef] [PubMed]

41. Ben Mohamed, H.; Vadel, A.M.; Geuns, J.M.C.; Khemira, H. Effects of Hydrogen Cyanamide on Antioxidant Enzymes' Activity, Proline and Polyamine Contents during Bud Dormancy Release in Superior Seedless Grapevine Buds. Acta Physiol. Plant. 2012, 34, 429-437. [CrossRef]

42. Dry, P.R. Canopy Management for Fruitfulness. Aust. J. Grape Wine Res. 2000, 6, 109-115. [CrossRef]

43. Guilpart, N.; Metay, A.; Gary, C. Grapevine Bud Fertility and Number of Berries per Bunch Are Determined by Water and Nitrogen Stress around Flowering in the Previous Year. Eur. J. Agron. 2014, 54, 9-20. [CrossRef]

44. Mujahid, Z.; Tounekti, T.; Khemira, H. Cold Plasma Treatment to Release Dormancy and Improve Growth in Grape Buds: A Promising Alternative to Natural Chilling and Rest Breaking Chemicals. Sci. Rep. 2020, 10, 2667. [CrossRef] [PubMed]

45. IPMA Instituto Português Do Mar e Da Atmosfera. Available online: https://www.ipma.pt/pt/publicacoes/boletins.jsp? $\mathrm{cmbDep}=\mathrm{cli} \& \mathrm{cmbTema}=\mathrm{pcl} \& \mathrm{cmbAno}=2016 \& i d D e p=c l i \& i d T e m a=p c l \& c u r A n o=2016$ (accessed on $1 \mathrm{June} 2021)$.

46. Smitha, R.B.; Bennans, T.; Mohankumar, C.; Benjamin, S. Oxidative Stress Enzymes in Ficus religiosa L.: Biochemical, Histochemical and Anatomical Evidences. J. Photochem. Photobiol. B Biol. 2009, 95, 17-25. [CrossRef] [PubMed]

47. Abassi, N.A.; Kushad, M.M.; Endress, A.G. Active Oxygen-Scavenging Enzymes Activities in Developing Apple Flowers and Fruits. Sci. Hortic. 1998, 74, 183-194. [CrossRef]

48. Nir, G.; Shulman, Y.; Fanberstein, L.; Lavee, S. Changes in the Activity of Catalase (EC 1.11.1.6) in Relation to the Dormancy of Grapevine (Vitis Vinifera L.) Buds. Plant Physiol. 1986, 81, 1140-1142. [CrossRef]

49. Perez, J.; Kliewer, W.M. Effect of Shading on Bud Necrosis and Bud Fruitfulness of Thompson Seedless Grapevines. Am. J. Enol. Vitic. 1990, 41, 168-175.

50. Liang, D.; Huang, X.; Shen, Y.; Shen, T.; Zhang, H.; Lin, L.; Wang, J.; Deng, Q.; Lyu, X.; Xia, H. Hydrogen Cyanamide Induces Grape Bud Endodormancy Release through Carbohydrate Metabolism and Plant Hormone Signaling. BMC Genom. 2019, 20, 1034. [CrossRef] [PubMed]

51. Sharma, P.; Jha, A.B.; Dubey, R.S.; Pessarakli, M. Reactive Oxygen Species, Oxidative Damage, and Antioxidative Defense Mechanism in Plants under Stressful Conditions. J. Bot. 2012, 2012, e217037. [CrossRef]

52. Mohamed, H.; Vadel, A.M.; Geuns, J.M.C.; Khemira, H. Biochemical Changes in Dormant Grapevine Shoot Tissues in Response to Chilling: Possible Role in Dormancy Release. Sci. Hortic. 2010, 124, 440-447. [CrossRef]

53. Chengguo, D.; Xianli, L.; Dongsheng, G.; Huanfang, L.; Meng, L. Studies on Regulations of Endogenous ABA and GA3 in Sweet Cherry Flower Buds on Dormancy. Acta Hortic. Sin. 2004, 31, 149.

54. El-Yazal, M.; Rady, M. Foliar-Applied Dormex ${ }^{\mathrm{TM}}$ or Thiourea-Enhanced Proline and Biogenic Amine Contents and Hastened Breaking Bud Dormancy in "Ain Shemer" Apple Trees. Trees 2013, 27, 161-169. [CrossRef]

55. El-Yazal, M.A.; El-Yazal, S.A.; Rady, M. Exogenous Dormancy-Breaking Substances Positively Change Endogenous Phytohormones and Amino Acids during Dormancy Release in 'Anna' Apple Trees. Plant Growth Regul. 2014, 72, 211-220. [CrossRef]

56. Bonhomme, M.; Peuch, M.; Ameglio, T.; Rageau, R.; Guilliot, A.; Decourteix, M.; Alves, G.; Sakr, S.; Lacointe, A. Carbohydrate Uptake from Xylem Vessels and Its Distribution among Stem Tissues and Buds in Walnut (Juglans Regia L.). Tree Physiol. 2010, 30, 89-102. [CrossRef] [PubMed]

57. Hussain, S.; Teng, Y.; Hamid, A.; Shah, S.Z.A.; Shah, H.; Yaqoob, A.; Ali, T.; Ahmed, M.; Hussain, I. Carbohydrate Changes during Dormancy Release in Floral, Vegetative Buds and Bark Tissues of Pear Cultivar 'Wonhwang' Cuttings Following Dormancy Breaking Agents Treatment. Int. J. Environ. Agric. Res. 2016, 2, 12. 
58. Kaufmann, H.; Blanke, M. Changes in Carbohydrate Levels and Relative Water Content (RWC) to Distinguish Dormancy Phases in Sweet Cherry. J Plant Physiol. 2017, 218, 1-5. [CrossRef]

59. Tixier, A.; Gambetta, G.A.; Godfrey, J.; Orozco, J.; Zwieniecki, M.A. Non-Structural Carbohydrates in Dormant Woody Perennials; The Tale of Winter Survival and Spring Arrival. Front. For. Glob. Chang. 2019, 2, 18. [CrossRef]

60. Signorelli, S.; Agudelo-Romero, P.; Meitha, K.; Foyer, C.H.; Considine, M.J. Roles for Light, Energy, and Oxygen in the Fate of Quiescent Axillary Buds. Plant Physiol. 2018, 176, 1171-1181. [CrossRef] [PubMed]

61. Vasudevan, L.; Wolf, T.K.; Welbaum, G.G.; Wisniewski, M.E. Reductions in Bud Carbohydrates Are Associated with Grapevine Bud Necrosis. Vitis 1998, 37, 189. [CrossRef]

62. Bennett, J.; Jarvis, P.; Trought, M.C.T. The Importance of Over-Wintering Carbohydrates on Inflorescence Development and Yield Potential. Aust. N. Z. Grapegrow. Winemak. 2002, 456, 70-72.

63. Bennett, J.; Jarvis, P.; Creasy, G.L.; Trought, M.C.T. Influence of Defoliation on Overwintering Carbohydrate Reserves, Return Bloom, and Yield of Mature Chardonnay Grapevines. Am. J. Enol. Vitic. 2005, 56, 386-393. 